\title{
Contribution of different processes to changes in tropical lower-stratospheric water vapor in chemistry-climate models
}

\author{
Kevin M. Smalley ${ }^{1}$, Andrew E. Dessler ${ }^{1}$, Slimane Bekki ${ }^{2}$, Makoto Deushi ${ }^{3}$, Marion Marchand ${ }^{2}$, Olaf Morgenstern ${ }^{4}$, \\ David A. Plummer ${ }^{5}$, Kiyotaka Shibata ${ }^{6}$, Yousuke Yamashita ${ }^{7, a}$, and Guang Zeng ${ }^{4}$ \\ ${ }^{1}$ Department of Atmospheric Sciences, Texas A\&M, College Station, Texas, USA \\ ${ }^{2}$ LATMOS, Institut Pierre Simon Laplace (IPSL), Paris, France \\ ${ }^{3}$ Meteorological Research Institute, 1-1 Nagamine, Tsukuba, Ibaraki 305-0052, Japan \\ ${ }^{4}$ National Institute of Water and Atmospheric Research (NIWA), Wellington, New Zealand \\ ${ }^{5}$ Canadian Centre for Climate Modelling and Analysis, Environment and Climate Change Canada, Montreal, Canada \\ ${ }^{6}$ School of Environmental Science and Engineering, Kochi University of Technology, Kami, Japan \\ ${ }^{7}$ National Institute for Environmental Studies (NIES), Tsukuba, Japan \\ a now at: Japan Agency for Marine-Earth Science and Technology (JAMSTEC), Yokohama, Japan
}

Correspondence to: Andrew Dessler (adessler@tamu.edu)

Received: 28 October 2016 - Discussion started: 8 November 2016

Revised: 15 May 2017 - Accepted: 29 May 2017 - Published: 4 July 2017

\begin{abstract}
Variations in tropical lower-stratospheric humidity influence both the chemistry and climate of the atmosphere. We analyze tropical lower-stratospheric water vapor in 21st century simulations from 12 state-of-the-art chemistry-climate models (CCMs), using a linear regression model to determine the factors driving the trends and variability. Within CCMs, warming of the troposphere primarily drives the long-term trend in stratospheric humidity. This is partially offset in most CCMs by an increase in the strength of the Brewer-Dobson circulation, which tends to cool the tropical tropopause layer (TTL). We also apply the regression model to individual decades from the 21 st century CCM runs and compare them to a regression of a decade of observations. Many of the CCMs, but not all, compare well with these observations, lending credibility to their predictions. One notable deficiency is that most CCMs underestimate the impact of the quasi-biennial oscillation on lowerstratospheric water vapor. Our analysis provides a new and potentially superior way to evaluate model trends in lowerstratospheric humidity.
\end{abstract}

\section{Introduction}

Stratospheric water vapor is well known to be a greenhouse gas (e.g., Manabe and Wetherald, 1967; Forster and Shine, 1999; Solomon et al., 2010; Maycock et al., 2014). Because of this, understanding the processes that control the humidity of air entering the tropical lower stratosphere (hereafter $\left[\mathrm{H}_{2} \mathrm{O}\right]_{\text {entry }}$ ) has been a high priority of the scientific community since Brewer (1949) first described stratospheric circulation.

It is now well established that the fundamental control over $\left[\mathrm{H}_{2} \mathrm{O}\right]_{\text {entry }}$ comes from the cold temperatures found in the tropical tropopause layer (TTL) (Fueglistaler et al., 2009b), and that variability in these temperatures translates into variability in $\left[\mathrm{H}_{2} \mathrm{O}\right]_{\text {entry. }}$. The most well-known example of this is the so-called "tape recorder", in which the seasonal cycle in TTL temperatures is imprinted on tropical stratospheric water vapor (Mote et al., 1996).

On interannual timescales, variability in $\left[\mathrm{H}_{2} \mathrm{O}\right]_{\text {entry }}$ originates from variability in the Brewer-Dobson circulation (BDC) (Randel et al., 2006; Castanheira et al., 2012; Fueglistaler et al., 2014; Gilford et al., 2016) and the quasi-biennial oscillation (QBO; O'Sullivan and Dunkerton, 1997; Randel et al., 1998; Dunkerton, 2001; Fueglistaler and Haynes, 2005; Choiu et al., 2006; Liang et al., 2011; 
Table 1. Chemistry-climate models (CCMs) used in this analysis. The resolution is listed as (lat $\times$ long $\times$ number of pressure levels). Thirty-one vertical levels indicates CCM data is given on isobaric levels, while CCMs simulating data on $>31$ levels are given on sigma (hybrid-pressure) levels. Abbreviations are as follows: quasi-biennial oscillation (QBO); Center for Climate System Research/National Institute for Environmental Studies (CCSR/NIES); Model for Interdisciplinary Research on Climate (MIROC); Canadian Middle Atmosphere Model (CMAM); Chemistry-Climate Model Initiative; Centre National de Recherches Météorologiques (CNRM); Goddard Earth Observing System Chemistry-Climate Model (GEOSCCM); Laboratorie de Meteorologie Dynamique Zoom-REPROBUS (LMDZrepro); Meteorological Research Institute (MRI); National Institute of Water and Atmospheric Research (NIWA); United Kingdom Chemistry and Aerosols (UKCA); Whole Atmosphere Community Climate Model (WACCM); Chemistry-Climate Model Initiative (CCMI).

\begin{tabular}{|c|c|c|c|c|c|}
\hline CCM & Resolution & Data set & Contains QBO & Institution & Reference(s) \\
\hline CCSR/NIES & $2.8^{\circ} \times 2.8^{\circ} \times 31$ & CCMVal-2 & No & NIES, Tsukuba, Japan & Akiyoshi et al. (2009) \\
\hline CCSR/NIES-MIROC3.2 & $2.8^{\circ} \times 2.8^{\circ} \times 34$ & CCMI-1 & Yes & NIES, Tsukuba, Japan & $\begin{array}{l}\text { Imai et al. (2013); Akiyoshi } \\
\text { et al. (2016) }\end{array}$ \\
\hline CMAM & $5.5^{\circ} \times 5.6^{\circ} \times 31$ & CCMVal-2 & No & EC, Canada & Scinocca et al. (2008) \\
\hline CMAM-CCMI & $3.7^{\circ} \times 3.8^{\circ} \times 71$ & CCMI-1 & No & EC, Canada & $\begin{array}{l}\text { Jonsson et al. (2004); } \\
\text { Scinocca et al. (2008) }\end{array}$ \\
\hline CNRM-CM5-3 & $2.8^{\circ} \times 2.8^{\circ} \times 31$ & CCMI-1 & No & Meteo-France, France & $\begin{array}{l}\text { Voldire et al. (2013); Mi- } \\
\text { chou et al. (2011) }\end{array}$ \\
\hline GEOSCCM & $2.0^{\circ} \times 2.5^{\circ} \times 31$ & CCMVal-2 & No & NASA/GSFC, USA & Pawson et al. (2008) \\
\hline GEOSCCM-CCMI & $2.0^{\circ} \times 2.5^{\circ} \times 72$ & CCMI-1 & Yes & NASA/GSFC, USA & $\begin{array}{l}\text { Molod et al. }(2012,2015) \text {; } \\
\text { Oman et al. }(2011,2013)\end{array}$ \\
\hline LMDZrepro & $2.5^{\circ} \times 3.8^{\circ} \times 31$ & CCMVal-2 & No & IPSL, France & Jourdain et al. (2008) \\
\hline MRI & $2.8^{\circ} \times 2.8^{\circ} \times 31$ & CCMVal-2 & Yes & MRI, Japan & Shibata and Deushi (2008) \\
\hline MRI-ESM1r1 & $2.8^{\circ} \times 2.8^{\circ} \times 80$ & CCMI-1 & Yes & MRI, Japan & $\begin{array}{l}\text { Yukimoto et al. (2011, } \\
\text { 2012); Deushi and Shibata } \\
\text { (2011) }\end{array}$ \\
\hline NIWA-UKCA & $2.5^{\circ} \times 3.8^{\circ} \times 31$ & CCMI-1 & Yes & NIWA, NZ & $\begin{array}{l}\text { Morgenstern et al. (2009, } \\
\text { 2013) }\end{array}$ \\
\hline WACCM & $1.9^{\circ} \times 2.5^{\circ} \times 31$ & CCMVal-2 & No & NCAR, USA & Garcia et al. (2007) \\
\hline
\end{tabular}

Castanheira et al., 2012; Khosrawi et al., 2013; Kawatani et al., 2014; Tao et al., 2015). Dessler et al. (2013, 2014) suggest that the temperature of the troposphere also exerts an influence on $\left[\mathrm{H}_{2} \mathrm{O}\right]_{\text {entry }}$ based primarily on an analysis of satellite measurements of $\left[\mathrm{H}_{2} \mathrm{O}\right]_{\text {entry. This is mainly caused by }}$ radiative heating of the TTL from increased upwelling radiation from a warming troposphere (Lin et al., 2017). In addition to this mechanism, Dessler et al. (2016) demonstrated in two CCMs that a warming climate also increases the amount of water directly injected into the stratosphere via deep convection, providing another mechanism for tropospheric temperature to affect $\left[\mathrm{H}_{2} \mathrm{O}\right]_{\text {entry }}$.

Putting these factors together, Dessler et al. $(2013,2014)$ demonstrated that observed $\left[\mathrm{H}_{2} \mathrm{O}\right]_{\text {entry }}$ anomalies could be accurately reproduced with a simple linear model:

$$
\left[\mathrm{H}_{2} \mathrm{O}\right]_{\text {entry }}=\beta_{0}+\beta_{\Delta T} \Delta T+\beta_{\mathrm{BDC}} \mathrm{BDC}+\beta_{\mathrm{QBO}} \mathrm{QBO}+\epsilon,
$$

where $\Delta T$ is the temperature of the troposphere, BDC is the strength of the Brewer-Dobson circulation, QBO represents the phase of the QBO, and $\epsilon$ is the residual. Dessler et al. (2013) analyzed the 21st century trend in one chemistryclimate model (hereafter, CCM; similar to general circulation models, but with a more realistic stratosphere and higher vertical resolution in the TTL) and found that the regression model worked well in reproducing the CCM's $\left[\mathrm{H}_{2} \mathrm{O}\right]_{\text {entry }}$ trend over the 21 st century. They concluded that the increase in $\left[\mathrm{H}_{2} \mathrm{O}\right]_{\text {entry }}$ was driven by the increase in tropospheric temperatures, which was partially offset by a strengthening BDC.

The Dessler et al. (2013) regression method provides a novel way to examine the regulation of $\left[\mathrm{H}_{2} \mathrm{O}\right]_{\text {entry }}$ in CCMs and compare it to observations. The purpose of this paper is to see whether this linear decomposition of $\left[\mathrm{H}_{2} \mathrm{O}\right]_{\text {entry }}$ variability holds in most CCMs and whether the same factors dominate.

\section{Models}

We analyze model output from six CCMs participating in Phase 2 of the Chemistry-Climate Model Validation Project (CCMVal-2; Morgenstern et al., 2010; SPARC, 2010) and output from six CCMs participating in Phase 1 of the Chemistry-Climate Model Initiative (CCMI-1; Morgenstern et al., 2017). Table 1 lists the model specifics and documentation.

We use simulations from the REF-B2 scenario of CCMVal-2. In this scenario, greenhouse gas concentrations during the 21st century come from the A1B scenario, which lies in the middle of the Special Report on Emissions Scenarios (SRES; IPCC, 2001). Ozone-depleting substances 


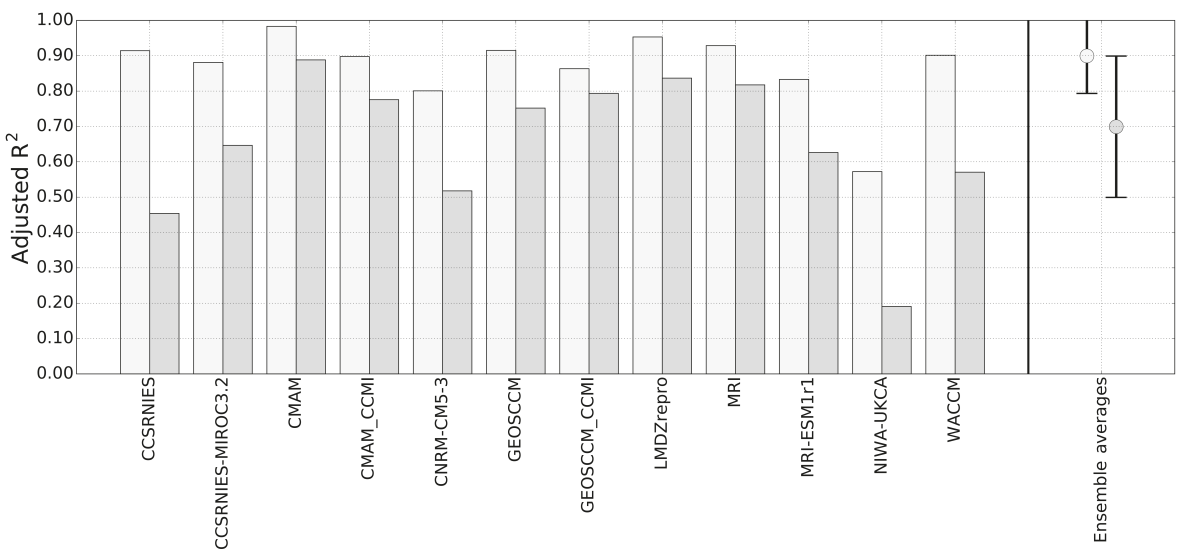

Figure 1. Bars show trended (light grey) and detrended (dark grey) adjusted $R^{2}$ values for annual-averaged data. The circles represent the ensemble mean, with error bars indicating \pm 1 standard deviation of the CCM ensemble.

come from the halogen emission scenario A1 (WMO, 2007). Specifics on CCMVal-2 can be found in SPARC (2010) and Morgenstern et al. (2010). We use the refC2 scenario of the CCMI-1. In this scenario, greenhouse gas concentrations come from the RCP6.0 scenario (Meinshausen et al., 2011) and ozone-depleting substances come from the halogen emission scenario A1 (WMO, 2014). CCMI-1 model specifics can be found in Morgenstern et al. (2017). In order to maintain a consistent reference period between models, our analysis covers 2000-2097, which we will hereafter refer to as "the 21 st century".

For each model, we fit $\mathrm{CCM}\left[\mathrm{H}_{2} \mathrm{O}\right]_{\text {entry }}$ using the multivariate linear regression (MLR) model described above. We use tropical average $80 \mathrm{hPa}$ water vapor volume mixing ratio as a proxy for $\left[\mathrm{H}_{2} \mathrm{O}\right]_{\text {entry }}$ (all tropical averages in this paper are averages over $30^{\circ} \mathrm{N}-30^{\circ} \mathrm{S}$ ).

For our BDC index, we use $80 \mathrm{hPa}$ diabatic heating rate (see Fueglistaler et al., 2009a, for details). Within models, studies have shown that the strength of the BDC increases throughout the 21 st century, primarily resulting from increasing greenhouse gases (e.g., Austin and Li, 2006; Garcia and Randel, 2008; Li et al., 2008; Oman et al., 2008). Observations generally confirm that tropical upwelling into the lower stratosphere has strengthened (Bönisch et al., 2011; Randel and Thompson, 2011; Young et al., 2012; Sioris et al., 2014). However, the BDC is not a directly observable circulation, and different variables including trace gas abundances, residual velocity, mean age of the air, and diabatic heating have been used (Rosenlof et al., 1997; Randel et al., 2006; Okamoto et al., 2011; Seviour et al., 2012; Stiller et al., 2012). Thus, depending on the variable used, the strength of the connection between the BDC term and $\left[\mathrm{H}_{2} \mathrm{O}\right]_{\text {entry }}$ may change.

The tropospheric temperature index is the $500 \mathrm{hPa}$ tropical average temperature. For the few CCMI-1 simulations that only produce variables on hybrid pressure levels (CMAMCCMI, CCSR/NIES-MIROC3.2, and MRI-ESM1r1), we choose a hybrid pressure level close to the $500 \mathrm{hPa}$ pressure surface (See Table 1). For the QBO index, we take the standardized anomaly of equatorial $50 \mathrm{hPa}$ zonal winds (anomalies in this paper are calculated by subtracting the mean seasonal cycle). By examining 21 st century $50 \mathrm{hPa}$ zonal winds (shown in the figures in the Supplement), we find that only 5 of the 12 models simulate a QBO (Table 1). As a result, we do not expect the QBO to significantly impact $\left[\mathrm{H}_{2} \mathrm{O}\right]_{\text {entry }}$ in many of the models.

All of these choices are similar to those used by Dessler et al. (2013, 2014). The MLR returns the coefficients for each regressor in Eq. (1), along with an uncertainty for each coefficient. Unless otherwise noted, we use $95 \%$ confidence intervals in this paper. Autocorrelation in the residuals is accounted for in the uncertainties following Santer et al. (2000). Finally, we will illustrate results with the MRI model; figures showing results derived from the other models can be found in the Supplement.

\section{$3 \quad 21$ st century analysis}

We first analyze the long-term trend in $\left[\mathrm{H}_{2} \mathrm{O}\right]_{\text {entry }}$ over the 21 st century. To do this, we calculate annual average values of $\left[\mathrm{H}_{2} \mathrm{O}\right]_{\text {entry }}$ and perform an MLR against annual averages of the indices for BDC, QBO, and $\Delta T$. For consistency, all annual average time series have had the 2000-2010 mean subtracted out. Most models simulate $\left[\mathrm{H}_{2} \mathrm{O}\right]_{\text {entry }}$ increasing during the 21st century (Gettelman et al., 2010; Kim et al., 2013). However, recent observational studies have concluded that no significant historical trend in water vapor entering the lower stratosphere exists (Scherer et al., 2008; Hegglin et al., 2014; Dessler et al., 2014).

Figure 1 shows that the fits to most of the models generate adjusted $R^{2}$ values greater than 0.8 . The NIWA-UKCA 21 st century MLR has the lowest adjusted $R^{2}$, with a value of approximately 0.6 . Overall, this result confirms the result of 


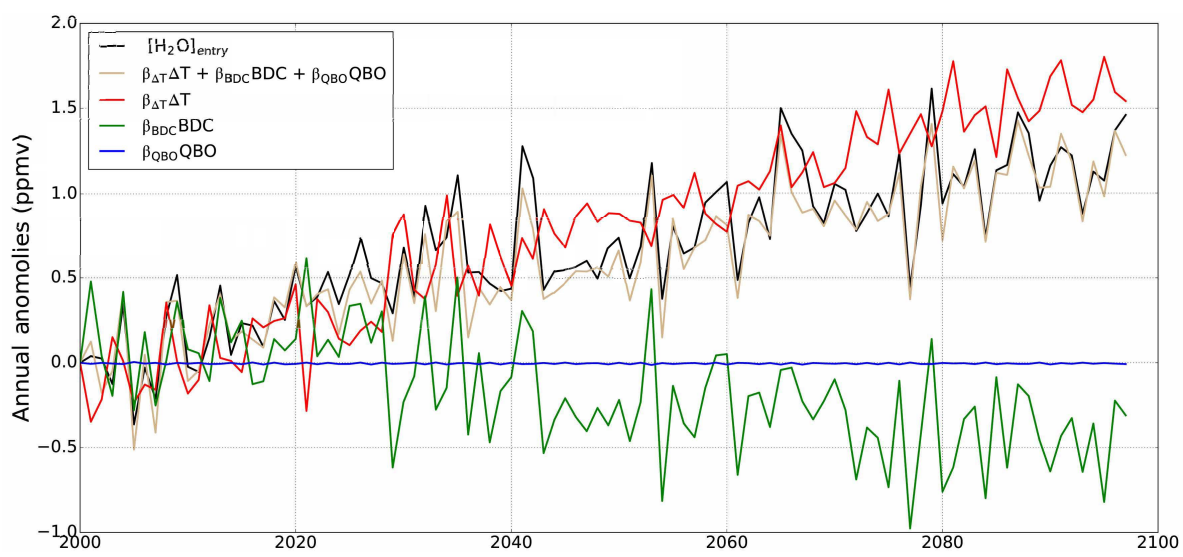

Figure 2. Time series of annual-averaged anomalies of $\left[\mathrm{H}_{2} \mathrm{O}\right]_{\text {entry }}$ from the MRI (black), and its reconstruction using a multivariate linear regression (brown). The red, green, and blue lines are the $\Delta T$, BDC, and QBO terms from the regression, respectively.

Dessler et al. (2013) that the regression model does a good job reproducing the $\mathrm{CCMs}{ }^{\prime}\left[\mathrm{H}_{2} \mathrm{O}\right]_{\text {entry }}$. Because we have left long-term trends in the time series, we will refer to this as the "trended analysis".

\subsection{Detrended 21st century}

One concern with the trended analysis is that the $\left[\mathrm{H}_{2} \mathrm{O}\right]_{\text {entry }}$, $\mathrm{BDC}$, and $\Delta T$ time series are all dominated by long-term trends. In such a case, an MLR may produce a high adjusted $R^{2}$ even if there is no actual relationship between the variables. To eliminate the influence of long-term trends on adjusted $R^{2}$, we detrend each variable using a Fourier transform filter (Donnelly, 2006) to remove long-term variability ( $>10$ years). We then use the MLR on the detrended $\left[\mathrm{H}_{2} \mathrm{O}\right]_{\text {entry }}$ and the detrended indices. Detrending by removing the long-term linear trend yields similar results.

Figure 1 shows the adjusted $R^{2}$ for the detrended calculation. For most of the models, the adjusted $R^{2}$ for the detrended MLR is moderately smaller than that for the trended one. This confirms that the long-term trends in the data tend to inflate the adjusted $R^{2}$, at least somewhat. But we also confirm that the models' detrended $\left[\mathrm{H}_{2} \mathrm{O}\right]_{\text {entry }}$ is also well represented by the same linear model (Eq. 1). Large differences do exist for some CCMs. For instance, the CCSR/NIES trended century MLR captures approximately $90 \%$ of the variance in $\left[\mathrm{H}_{2} \mathrm{O}\right]_{\text {entry }}$, while the detrended 21st century MLR only explains about $40 \%$ of detrended variance; CNRM-CM5-3, NIWA-UKCA, and WACCM show something similar.

\subsection{Physical process effects}

The coefficients from the trended and detrended calculations are listed in Tables 2 and 3, respectively. The product of the regression coefficient and its index quantifies the impact of the process on $\left[\mathrm{H}_{2} \mathrm{O}\right]_{\text {entry }}$. As an example, MRI $\left[\mathrm{H}_{2} \mathrm{O}\right]_{\text {entry }}$ increases by about 1.2 ppmv during the 21 st century (Fig. 2). The regression shows that this is the result of a large in- crease in $\left[\mathrm{H}_{2} \mathrm{O}\right]_{\text {entry }}$ due to $\Delta T$ increases $(\sim 1.5 \mathrm{ppmv})$ that is offset by a strengthening BDC, which reduces $\left[\mathrm{H}_{2} \mathrm{O}\right]_{\text {entry }}$ by approximately $0.3 \mathrm{ppmv}$. The regression finds virtually no change in $\left[\mathrm{H}_{2} \mathrm{O}\right]_{\text {entry }}$ in response to the QBO.

Figure 3 shows that $\left[\mathrm{H}_{2} \mathrm{O}\right]_{\text {entry }}$ increases as $\Delta T$ increases in all models and that the $\Delta T$ regression coefficients are similar for both trended and detrended MLRs. The coefficient for individual models ranges from 0.1 to $0.6 \mathrm{ppmv} \mathrm{K}^{-1}$, with an average of $0.32 \mathrm{ppmv} \mathrm{K}^{-1}$ and a standard deviation of $0.15 \mathrm{ppmv} \mathrm{K}^{-1}$. It is worth pointing out that the models can get the right answer for the wrong reason. For example, spurious diffusion of water vapor through the tropopause has been shown to be an issue in models (e.g., Gettelman et al., 2010; Hardiman et al., 2015). This may impact the relationship between $\left[\mathrm{H}_{2} \mathrm{O}\right]_{\text {entry }}$ and tropospheric warming, thereby biasing our results. However, Dessler et al. (2016) was able to accurately simulate the stratospheric trend in two CCMs using a diffusion-free trajectory model, showing that, in some models at least, this is not an issue.

This figure also shows that the BDC coefficient is generally negative, meaning that a strengthening BDC reduces $\left[\mathrm{H}_{2} \mathrm{O}\right]_{\text {entry }}$. This relationship arises from well established physics that a strengthening BDC should cool the tropopause, reducing water vapor entering the stratosphere (e.g., Holton et al., 1995). This anticorrelation between BDC strength and TTL temperatures has been observed (e.g., Yulaeva et al., 1994; Flury et al., 2013), and this has been identified as the cause of the stratospheric tape recorder (Mote et al., 1996). This anticorrelation has also been identified as the cause of the large drop in $\left[\mathrm{H}_{2} \mathrm{O}\right]_{\text {entry }}$ around 2000 (e.g., Randel et al., 2006; Dhomse et al., 2008). The coefficient for individual models ranges from -11.8 to $+4.3 \mathrm{ppmv}$ $(\mathrm{K} / \text { day })^{-1}$, with an average of $-3.55 \mathrm{ppmv}(\mathrm{K} / \text { day })^{-1}$ and a standard deviation of $4.45 \mathrm{ppmv}(\mathrm{K} / \mathrm{day})^{-1}$. Two models (CNRM-CM5-3 and NIWA-UKCA) yield positive BDC coefficients, indicating potential problems with these models. And the magnitude of the MRI BDC coefficients are about 
2 times larger than those produced by MRI-ESM1r1. This could explain why the detrended adjusted $R^{2}$ value for MRIESM1r1 is so much smaller than that of MRI.

Figure 3 shows that all QBO regression coefficients are small, generally within \pm 0.04 ppmv, with even the sign of the effect in doubt. Interestingly, one of the CCMs not simulating a QBO, CMAM-CCMI, produces the largest QBO regression coefficients of $0.082 \pm 0.04$ and $0.077 \pm 0.04 \mathrm{ppmv}$ for the trended and detrended calculations, respectively. Among CCMs that do simulate a QBO, the ensemble average QBO regression coefficient does not differ much from the same quantity (approximately 0 ppmv) for the other models. We will discuss this further in the next section.

As can be seen in the plots for individual models in the Supplement, the variability in $\left[\mathrm{H}_{2} \mathrm{O}\right]_{\text {entry }}$ in a few models comes almost entirely from the variability in BDC, with almost no variability in the $\Delta T$ time series (other than the longterm trend). That means that the $\Delta T$ term, which is almost a pure trend, will fit whatever is left after matching the interannual variability and trend of the QBO time series.

We have also calculated the long-term linear trend of $\left[\mathrm{H}_{2} \mathrm{O}\right]_{\text {entry }}$ for each model as well as the trend in each component of $\left[\mathrm{H}_{2} \mathrm{O}\right]_{\text {entry }}$, as determined by the multivariate fit (e.g., the trend in the components plotted in Fig. 2). We find that $\Delta T$ makes the largest contribution to the trend in $\left[\mathrm{H}_{2} \mathrm{O}\right]_{\text {entry }}$, with a smaller negative effect from the a strengthening BDC on $\left[\mathrm{H}_{2} \mathrm{O}\right]_{\text {entry }}$, and a trend of close to zero for the QBO (Fig. 4).

To provide additional information about the relative contribution from the individual terms in Eq. (1), we have also calculated the regression coefficient using standardized variables. To do this, we take each regression coefficient and multiply it by the standard deviation of the associated regressor index. The values are listed in Tables 2 and 3 and they confirm that, in the trended calculations, $\Delta T$ is the dominant cause of the trend in $\left[\mathrm{H}_{2} \mathrm{O}\right]_{\text {entry }}$. The BDC acts to reduce the trend, but its overall impact is much smaller than $\Delta T$.

In the detrended calculations, the standardized $\Delta T$ regression coefficients are smaller than those from the trended calculations, while the magnitude of the BDC coefficients remains relatively constant. This results in the BDC being more important than $\Delta T$ for short-term variability. In all of our calculations, we find that the QBO has little impact on $\left[\mathrm{H}_{2} \mathrm{O}\right]_{\text {entry }}$.

\section{Decadal analysis}

Ideally, we would compare the results of the last section to observations. Unfortunately, we do not have 100 years of observations to test the models against. Instead, we will compare regressions of 10-year segments from the CCMs to regressions of 10 years of observations. This will help us evaluate how good the models are and provide us with an indication of how representative a single decade is.
To do this, we split the 21st century of each CCM run into 10 decades (2000-2010, 2010-2020, 2020-2030, 20402050 , etc.) and fit each individual decade using the regression model (Eq. 1). The regression calculation used on each 10 -year segment is identical to the century analysis, except monthly averaged anomalies of all quantities are used instead of annual mean anomalies. Following Dessler et al. (2014), decadal regression terms are lagged in order to maximize MLR fit: we lag $\Delta T$ by 3 months, the BDC by 1 month, and the QBO by 3 months. These lags reflect the time between changes in each index and the impact on $\left[\mathrm{H}_{2} \mathrm{O}\right]_{\text {entry }}$.

Figure 5 shows the median \pm 1 standard deviation of the 10 decadal adjusted $R^{2}$ values generated by each CCM. The ensemble average is $0.61 \pm 0.25$, with some spread among the models. Also plotted are the adjusted $R^{2}$ values from two regressions of the tropical average Aura Microwave Limb Sounder (MLS) $82 \mathrm{hPa}$ water vapor mixing ratio observations from 2004-2014 (Dessler et al., 2014). One regression uses Modern-Era Retrospective Analysis for Research and Applications reanalysis (MERRA) (Rienecker et al., 2011) and the other uses European Centre for Medium-Range Weather Forecasts interim reanalysis (ERAI) (Dee et al., 2011) for the $\Delta T$ and BDC indices; the QBO index in both regressions are from observations, as calculated in Dessler et al. (2014).

Many of the models have a range of adjusted $R^{2}$ values that overlap with the observational regression. However, the models producing the smallest decadal adjusted $R^{2}$ values, CCSR/NIES, CNRM-CM5-3, and NIWA-UKCA, are also the models that produced the poorest fits to long-term de-

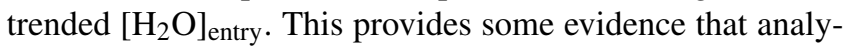
sis of just a decade of $\left[\mathrm{H}_{2} \mathrm{O}\right]_{\text {entry }}$ can provide insight into the long-term behavior of that quantity.

Figure 6 shows the median and 1 standard deviation of each coefficient (values are listed in Table 4), along with the coefficients from the regression of the MLS data (taken from Table 1 of Dessler et al., 2014). We find that the CCMs agree unanimously that increases in $\Delta T$ are associated with increased $\left[\mathrm{H}_{2} \mathrm{O}\right]_{\text {entry }}$, though the $\mathrm{CCM}$ ensemble tends to underestimate the observational estimate. The only models that do not fall within both observational ranges are CCSR/NIES, CMAM-CCMI, and CNRM-CM5-3.

In addition, the spread between the different decades for a single model tends to be small. The coefficient for individual models ranges from 0.01 to $0.4 \mathrm{ppmv} \mathrm{K}^{-1}$, with an average of $0.15 \mathrm{ppmv} \mathrm{K}^{-1}$ and a standard deviation of $0.11 \mathrm{ppmv} \mathrm{K}^{-1}$. This provides additional confidence that the comparison between the CCMs and 1 decade of observations is meaningful.

Figure 6 shows that there exists significant spread in the CCMs' decadal BDC regression coefficients. The coefficient for individual models ranges from -8.4 to $+2.9 \mathrm{ppmv}$ $(\mathrm{K} / \text { day })^{-1}$, with an average of $-3.55 \mathrm{ppmv}(\mathrm{K} / \text { day })^{-1}$ and a standard deviation of $3.58 \mathrm{ppmv}(\mathrm{K} / \mathrm{day})^{-1}$. On all timescales, we expect a strengthening BDC to cool the TTL and reduce $\left[\mathrm{H}_{2} \mathrm{O}\right]_{\text {entry }}$, so the coefficient should be negative. 


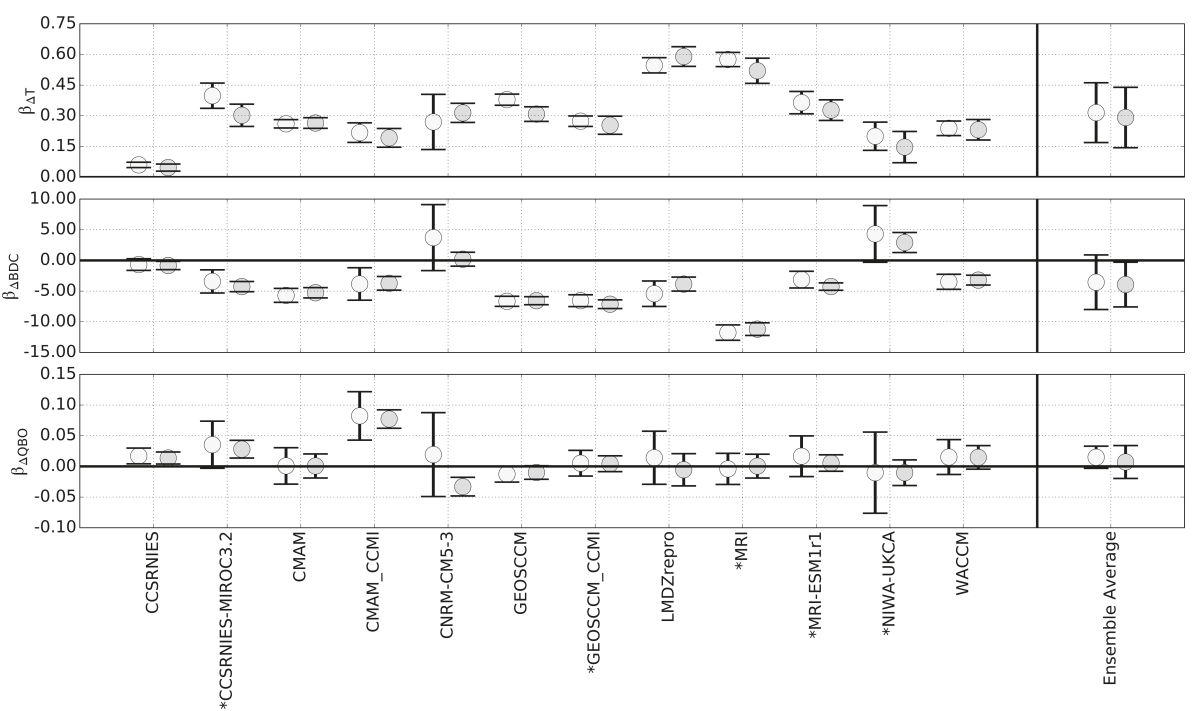

Figure 3. Circles show detrended (light grey) and trended (dark grey) coefficients for each model; error bars correspond to 95th percentile confidence interval bounding each regression coefficient. An asterisk indicates models simulating a QBO. The ensemble mean corresponds to the average of all model coefficients. The ensemble mean coefficients are also represented by a circle, with associated error bars corresponding to \pm 1 standard deviation of the ensemble. The units of $\beta_{\Delta t}, \beta_{\mathrm{BDC}}$, and $\beta_{\mathrm{QBO}}$ are ppmv $\mathrm{K}^{-1}$, ppmv (K/day) $)^{-1}$, and ppmv, respectively.

Table 2. Coefficients $(\beta \mathrm{s})$ from regressions of trended $\left[\mathrm{H}_{2} \mathrm{O}\right]_{\text {entry }}$ time series, and the change in $\left[\mathrm{H}_{2} \mathrm{O}\right]_{\text {entry }}$ resulting from each process $(\beta \operatorname{STD}())$, where $\operatorname{STD}()$ is the standard deviation of each trended process.

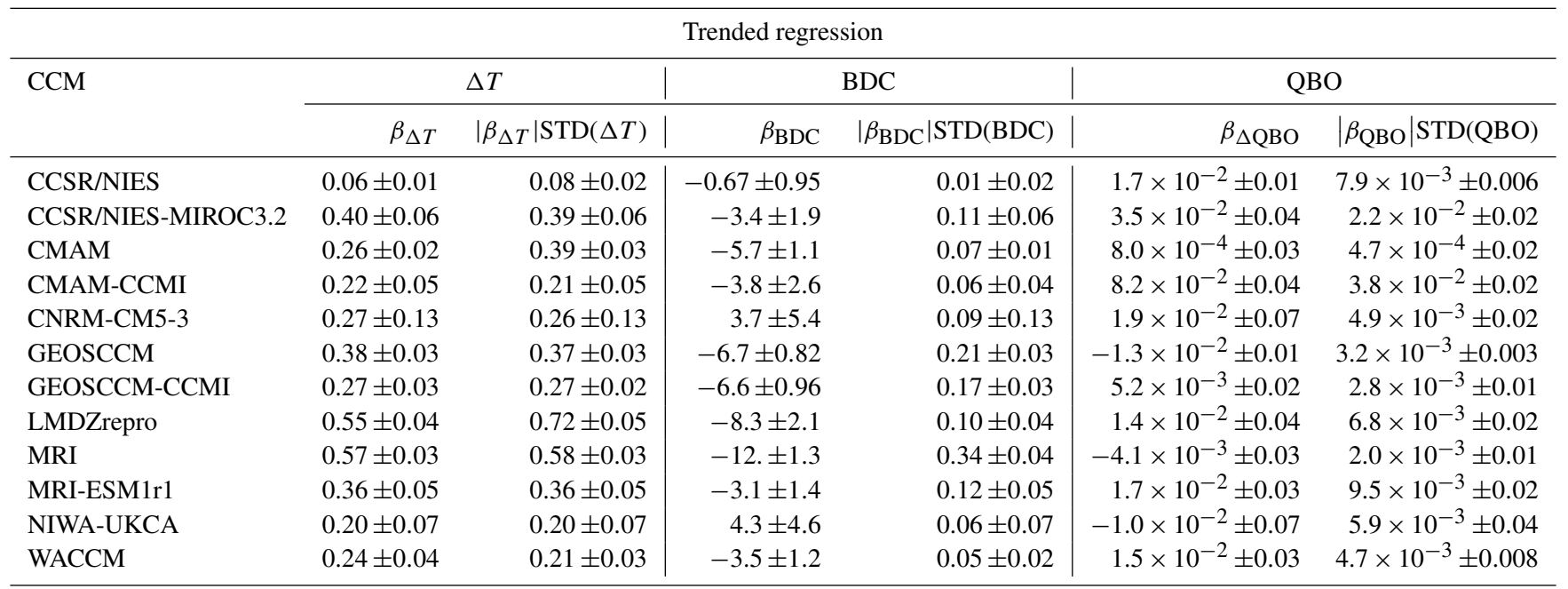

The units of $\Delta T$, BDC, and QBO are ppmv $\mathrm{K}^{-1}$, ppmv (K/day) ${ }^{-1}$, and ppmv, while the units of $\beta_{\Delta T} \mathrm{STD}(\Delta T), \beta_{\mathrm{BDC}} \mathrm{STD}(\mathrm{BDC})$, and $\beta_{\mathrm{QBO}} \mathrm{STD}(\mathrm{QBO})$ are all ppmv. The uncertainty is the $95 \%$ confidence interval.

We see that the median is indeed negative for all CCMs except for the CNRM-CM5-3 and NIWA-UKCA (these models also generated positive BDC coefficients for the century analysis).

When comparing with observations, we find that the model ensemble does well. The CCSR/NIES, CCSR/NIESMIROC-3.2, CMAM, CMAM-CCMI, LMDZrepro, MRIESM1r1, and WACCM decadal BDC regression coefficients fall within $95 \%$ confidence of MERRA, and the CCSR/NIES-MIROC-3.2, LMDZrepro, and WACCM fall within $95 \%$ confidence interval of ERAI. As with the $\Delta T$ coefficient, the spread between the different decades for a single model tends to be small.

Figure 6 shows that, for all CCMs, the ensemble average decadal QBO coefficient is approximately 0 ppmv. For those CCMs that do simulate a $\mathrm{QBO}$, the ensemble average coefficient is $0.02 \pm 0.03 \mathrm{ppmv}$. This is significantly smaller than the response to the QBO in the observations. Only CCSR/NIES-MIROC3.2 and CMAM-CCMI decadal regressions produce $\mathrm{QBO}$ coefficients approaching those from both 
Table 3. Coefficients $(\beta \mathrm{s})$ from regressions of detrended $\left[\mathrm{H}_{2} \mathrm{O}\right]_{\text {entry }}$ time series, and the change in $\left[\mathrm{H}_{2} \mathrm{O}\right]_{\text {entry }}$ resulting from each process $(\beta \operatorname{STD}())$, where $\operatorname{STD}()$ is the standard deviation of each detrended process.

\begin{tabular}{lrr|rr|rr}
\hline & \multicolumn{3}{c}{ Detrended regression } & \\
\hline & \multicolumn{2}{c|}{$\Delta T$} & \multicolumn{2}{c}{ BDC } & QBO \\
\cline { 2 - 7 } CCM & \multicolumn{2}{c|}{$\beta_{\Delta T}$} & $\left|\beta_{\Delta T}\right| \mathrm{STD}(\Delta T)$ & $\beta_{\mathrm{BDC}}$ & $\left|\beta_{\mathrm{BDC}}\right| \mathrm{STD}(\mathrm{BDC})$ & $\beta_{\Delta \mathrm{QBO}}\left|\beta_{\mathrm{QBO}}\right| \mathrm{STD}(\mathrm{QBO})$ \\
\hline CCSR/NIES & $0.05 \pm 0.02$ & $0.02 \pm 0.006$ & $-0.67 \pm 0.67$ & $7.1 \times 10^{-3} \pm 0.005$ & $1.7 \times 10^{-2} \pm 0.01$ & $3.6 \times 10^{-3} \pm 0.003$ \\
CCSR/NIES-MIROC3.2 & $0.30 \pm 0.05$ & $0.08 \pm 0.01$ & $-4.3 \pm 0.83$ & $0.08 \pm 0.02$ & $2.8 \times 10^{-2} \pm 0.01$ & $1.7 \times 10^{-2} \pm 0.009$ \\
CMAM & $0.26 \pm 0.03$ & $0.10 \pm 0.01$ & $-5.3 \pm 0.84$ & $0.05 \pm 0.008$ & $7.0 \times 10^{-4} \pm 0.02$ & $1.9 \times 10^{-4} \pm 0.006$ \\
CMAM-CCMI & $0.26 \pm 0.05$ & $0.05 \pm 0.01$ & $-3.7 \pm 1.1$ & $0.04 \pm 0.01$ & $7.7 \times 10^{-2} \pm 0.04$ & $2.9 \times 10^{-2} \pm 0.005$ \\
CNRM-CM5-3 & $0.19 \pm 0.05$ & $0.08 \pm 0.01$ & $0.20 \pm 1.1$ & $2.5 \times 10^{-3} \pm 0.01$ & $-3.3 \times 10^{-2} \pm 0.01$ & $7.1 \times 10^{-3} \pm 0.003$ \\
GEOSCCM & $0.31 \pm 0.04$ & $0.08 \pm 0.009$ & $-6.6 \pm 0.65$ & $0.09 \pm 0.009$ & $-1.0 \times 10^{-2} \pm 0.01$ & $1.9 \times 10^{-3} \pm 0.002$ \\
GEOSCCM-CCMI & $0.25 \pm 0.04$ & $0.07 \pm 0.01$ & $-7.1 \pm 0.71$ & $0.17 \pm 0.03$ & $4.4 \times 10^{-3} \pm 0.01$ & $2.3 \times 10^{-3} \pm 0.007$ \\
LMDZrepro & $0.59 \pm 0.05$ & $0.25 \pm 0.02$ & $-5.4 \pm 1.1$ & $0.05 \pm 0.02$ & $-5.5 \times 10^{-3} \pm 0.03$ & $2.3 \times 10^{-3} \pm 0.01$ \\
MRI & $0.52 \pm 0.03$ & $0.18 \pm 0.02$ & $-11.2 \pm 1.0$ & $0.24 \pm 0.02$ & $-4.6 \times 10^{-4} \pm 0.02$ & $2.2 \times 10^{-4} \pm 0.01$ \\
MRI-ESM1r1 & $0.33 \pm 0.05$ & $0.09 \pm 0.01$ & $-4.3 \pm 0.61$ & $0.10 \pm 0.01$ & $5.5 \times 10^{-3} \pm 0.01$ & $3.0 \times 10^{-3} \pm 0.007$ \\
NIWA-UKCA & $0.15 \pm 0.08$ & $0.04 \pm 0.02$ & $2.9 \pm 1.6$ & $0.04 \pm 0.02$ & $-1.0 \times 10^{-2} \pm 0.02$ & $5.9 \times 10^{-3} \pm 0.01$ \\
WACCM & $0.23 \pm 0.05$ & $0.06 \pm 0.01$ & $-3.5 \pm 0.80$ & $0.04 \pm 0.01$ & $1.5 \times 10^{-2} \pm 0.02$ & $2.8 \times 10^{-3} \pm 0.004$ \\
\hline
\end{tabular}

The units of $\Delta T$, BDC, and $\mathrm{QBO}$ are ppmv $\mathrm{K}^{-1}$, ppmv $(\mathrm{K} / \mathrm{day})^{-1}$, and ppmv, while the units of $\beta_{\Delta T} \mathrm{STD}(\Delta T), \beta_{\mathrm{BDC}} \mathrm{STD}(\mathrm{BDC})$, and $\beta_{\mathrm{QBO}} \mathrm{STD}(\mathrm{QBO})$ are all ppmv. The uncertainty is the $95 \%$ confidence interval.

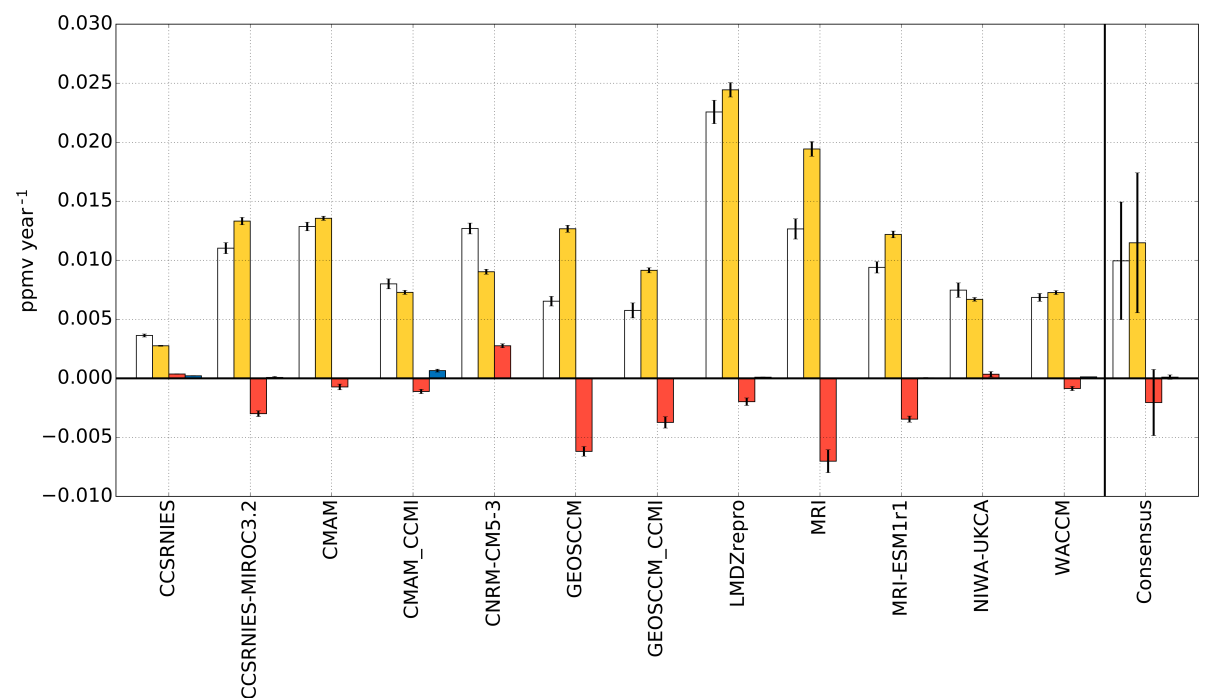

Figure 4. Trends in $\left[\mathrm{H}_{2} \mathrm{O}\right]_{\text {entry }}$ (white) resulting from $\Delta T$ (yellow), BDC (red), and QBO (blue) predictor time series assuming the other predictors are held constant. Error bars represent $95 \%$ uncertainty. For many models, the contribution of the QBO is too small to be seen.

observational regressions. Again, CMAM-CCMI does not simulate a QBO, and it is not clear to us why the model does so well in this aspect of our analysis.

Previous studies found that the QBO significantly influences TTL temperatures and subsequently $\left[\mathrm{H}_{2} \mathrm{O}\right]_{\text {entry }}$ ( $\mathrm{Zhou}$ et al., 2001; Geller et al., 2002; Liang et al., 2011), so the lack of response in the model ensemble appears to be a problem in the models. Previous studies have investigated this issue, finding that a higher vertical resolution within the stratosphere can help resolve the QBO's impact on the lower stratosphere (Rind et al., 2014; Anstey et al., 2016; Geller et al., 2016). Clearly, this needs to be investigated further.
Similar to both the trended and detrended regression analysis, we calculated the regression coefficients using standardized variables of the decadal analysis, and the values are listed in Table 4. Within most models, we see that the BDC, on decadal timescales, has the largest impact on $\left[\mathrm{H}_{2} \mathrm{O}\right]_{\text {entry }}$, with $\Delta T$ having a smaller impact.

\section{Century and decadal regression coefficient comparison}

One interesting question is whether or not the regression coefficients from the decadal analyses are related to regression 


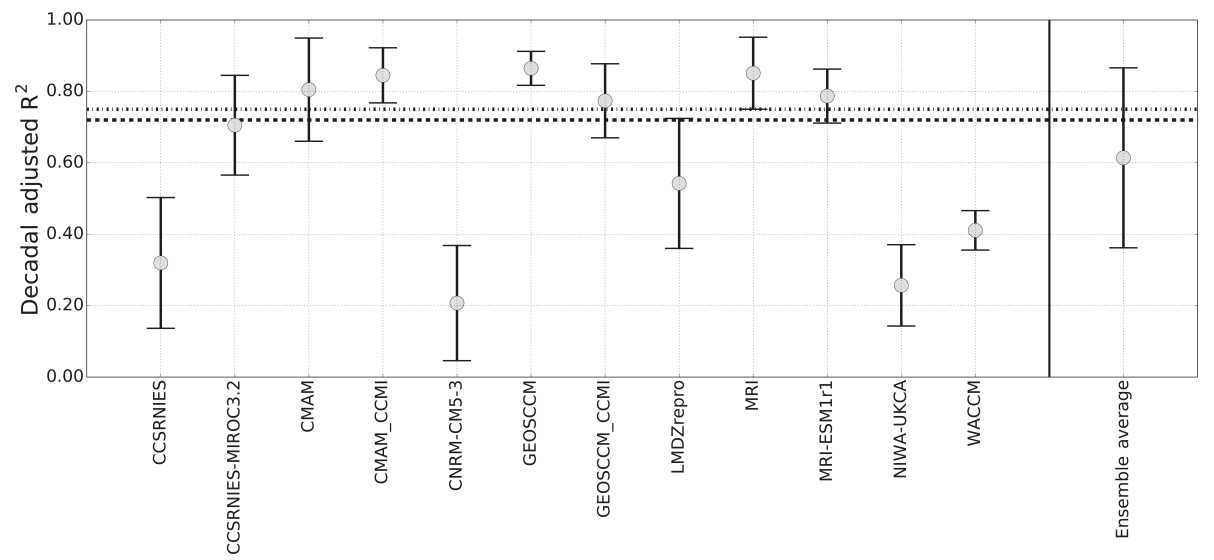

Figure 5. Circles represent the median of the adjusted $R^{2}$ value of the decadal fits. Errors correspond to the \pm 1 standard deviation of the adjusted $R^{2}$ values. The CCM ensemble average is also plotted, along with error bars corresponding to \pm 1 standard deviation of the ensemble set of decadal adjusted $R^{2}$ values. The lines are adjusted $R^{2}$ values from observations combined with reanalysis (ERAI (dotted) and MERRA (dashed)) from Dessler et al. (2014).

Table 4. Median coefficients from the decadal regressions of $\left[\mathrm{H}_{2} \mathrm{O}\right]_{\text {entry }}$ monthly anomalies, and the change in $\left[\mathrm{H}_{2} \mathrm{O}\right]$ entry resulting from each process $(\beta \operatorname{STD}())$, where $\mathrm{STD}()$ is the standard deviation of each decadal process.

\begin{tabular}{lrr|rr|rr}
\hline & \multicolumn{3}{c}{ Decadal regressions } \\
\hline CCM & \multicolumn{2}{c|}{$\Delta T$} & \multicolumn{2}{c}{ BDC } & \multicolumn{2}{c}{ QBO } \\
\cline { 2 - 8 } & \multicolumn{2}{c|}{$\beta_{\Delta T}$} & $\left|\beta_{\Delta T}\right| \mathrm{STD}(\Delta T)$ & $\beta_{\mathrm{BDC}}$ & $\left|\beta_{\mathrm{BDC}}\right| \mathrm{STD}(\mathrm{BDC})$ & $\beta_{\Delta \mathrm{QBO}}\left|\beta_{\mathrm{QBO}}\right| \mathrm{STD}(\mathrm{QBO})$ \\
\hline CCSR/NIES & $0.03 \pm 0.04$ & $8.7 \times 10^{-3} \pm 0.01$ & $-1.23 \pm 1.34$ & $0.01 \pm 0.02$ & $5.26 \times 10^{-3} \pm 0.02$ & $1.5 \times 10^{-3} \pm 0.005$ \\
CCSR/NIES-MIROC3.2 & $0.10 \pm 0.17$ & $0.03 \pm 0.02$ & $-3.29 \pm 1.44$ & $0.10 \pm 0.04$ & $6.05 \times 10^{-2} \pm 0.01$ & $5.7 \times 10^{-2} \pm 0.02$ \\
CMAM & $0.19 \pm 0.09$ & $0.05 \pm 0.03$ & $-6.06 \pm 1.34$ & $0.07 \pm 0.02$ & $2.75 \times 10^{-3} \pm 0.03$ & $9.4 \times 10^{-4} \pm 0.004$ \\
CMAM-CCMI & $0.01 \pm 0.10$ & $3.5 \times 10^{-3} \pm 0.02$ & $-4.70 \pm 1.29$ & $0.07 \pm 0.03$ & $6.13 \times 10^{-2} \pm 0.01$ & $3.0 \times 10^{-2} \pm 0.02$ \\
CNRM-CM5-3 & $0.06 \pm 0.14$ & $0.01 \pm 0.03$ & $2.89 \pm 1.44$ & $0.05 \pm 0.02$ & $1.84 \times 10^{-2} \pm 0.02$ & $4.9 \times 10^{-3} \pm 0.01$ \\
GEOSCCM & $0.17 \pm 0.10$ & $0.04 \pm 0.02$ & $-6.31 \pm 1.19$ & $0.13 \pm 0.03$ & $-1.47 \times 10^{-2} \pm 0.03$ & $4.9 \times 10^{-3} \pm 0.005$ \\
GEOSCCM-CCMI & $0.11 \pm 0.16$ & $0.02 \pm 0.03$ & $-8.00 \pm 1.89$ & $0.18 \pm 0.06$ & $2.42 \times 10^{-2} \pm 0.02$ & $1.8 \times 10^{-2} \pm 0.01$ \\
LMDZrepro & $0.31 \pm 0.19$ & $0.11 \pm 0.08$ & $-2.71 \pm 2.71$ & $0.07 \pm 0.05$ & $1.27 \times 10^{-2} \pm 0.01$ & $6.9 \times 10^{-3} \pm 0.03$ \\
MRI & $0.35 \pm 0.09$ & $0.12 \pm 0.04$ & $-8.78 \pm 2.91$ & $0.25 \pm 0.07$ & $-6.56 \times 10^{-3} \pm 0.06$ & $4.6 \times 10^{-3} \pm 0.03$ \\
MRI-ESM1r1 & $0.19 \pm 0.04$ & $0.05 \pm 0.01$ & $-4.72 \pm 0.71$ & $0.13 \pm 0.03$ & $1.17 \times 10^{-2} \pm 0.03$ & $8.9 \times 10^{-3} \pm 0.02$ \\
NIWA-UKCA & $0.05 \pm 0.29$ & $0.01 \pm 0.06$ & $2.11 \pm 3.26$ & $0.04 \pm 0.05$ & $-1.88 \times 10^{-2} \pm 0.04$ & $1.5 \times 10^{-2} \pm 0.03$ \\
WACCM & $0.15 \pm 0.12$ & $0.03 \pm 0.03$ & $-2.25 \pm 0.85$ & $0.05 \pm 0.02$ & $3.84 \times 10^{-2} \pm 0.03$ & $9.1 \times 10^{-3} \pm 0.007$ \\
\hline MLS/ERAI & $0.34 \pm 0.17$ & $0.11 \pm 0.05$ & $-2.5 \pm 0.83$ & $0.17 \pm 0.06$ & $1.1 \times 10^{-1} \pm 0.04$ \\
MLS/MERRA & $0.30 \pm 0.20$ & $0.11 \pm 0.07$ & $-3.5 \pm 1.6$ & $0.15 \pm 0.07$ & $1.2 \times 10^{-1} \pm 0.05$ & $0.11 \pm 0.05$ \\
\hline
\end{tabular}

The units of $\Delta T, \mathrm{BDC}$, and $\mathrm{QBO}$ are ppmv $\mathrm{K}^{-1}$, ppmv $(\mathrm{K} / \mathrm{day})^{-1}$, and ppmv, while the units of $\beta_{\Delta T} \mathrm{STD}(\Delta T), \beta_{\mathrm{BDC}} \mathrm{STD}(\mathrm{BDC})$, and $\beta_{\mathrm{OBO}} \mathrm{STD}(\mathrm{QBO})$ are all ppmv.

The uncertainty represents the variability (1 standard deviation) in the set of coefficients produced by each CCM. For observations, the error bars represent $95 \%$ confidence.

coefficients from century regressions. To answer this, Fig. 7 shows the coefficients from the trended century regressions of each CCM plotted against the median of the decadal regressions from the same CCM. Also shown is a linear leastsquares fit to the points. For the $\Delta T$ coefficient, the best-fit line is

$$
\begin{aligned}
& \beta(\Delta T, \text { century })=1.21 \pm 0.44 \beta(\Delta T, \text { decade }) \\
& \quad+0.13 \pm 0.08
\end{aligned}
$$

All uncertainties are $95 \%$ confidence intervals. Thus, the $\Delta T$ coefficients from the trended MLRs are slightly larger than those from the decadal MLRs. Using values of $\beta(\Delta T$, decade) from MLS observations and this fit, we predict $\beta\left(\Delta T\right.$, century) of $0.50 \pm 0.06$ and $0.55 \pm 0.08$ ppmv K$^{-1}$ for MERRA and ERAI regressions, respectively. 


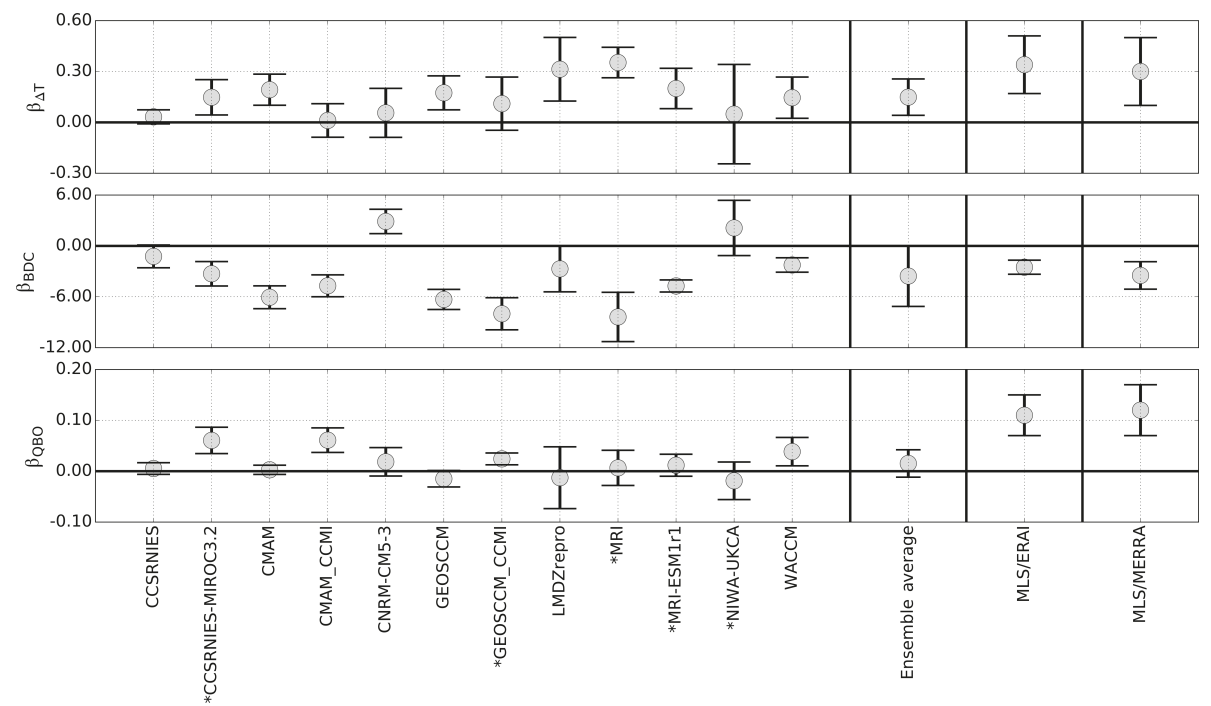

Figure 6. Circles represent the median decadal regression coefficient from each CCM, and error bars correspond to \pm 1 standard deviation. An asterisk indicates that the model simulates a QBO. The ensemble mean corresponds to an average of all model coefficients. The ensemble mean coefficients are also represented by a circle, with associated error bars correspond to \pm 1 standard deviation of the ensemble set of coefficients. Estimates from observations combined with reanalysis (Dessler et al., 2014) are shown, along with 95th percentile confidence interval. The units of $\beta_{\Delta t}, \beta_{\mathrm{BDC}}$, and $\beta_{\mathrm{QBO}}$ are $\mathrm{ppmv} \mathrm{K}^{-1}$, ppmv/(K/day $)^{-1}$, and ppmv, respectively.
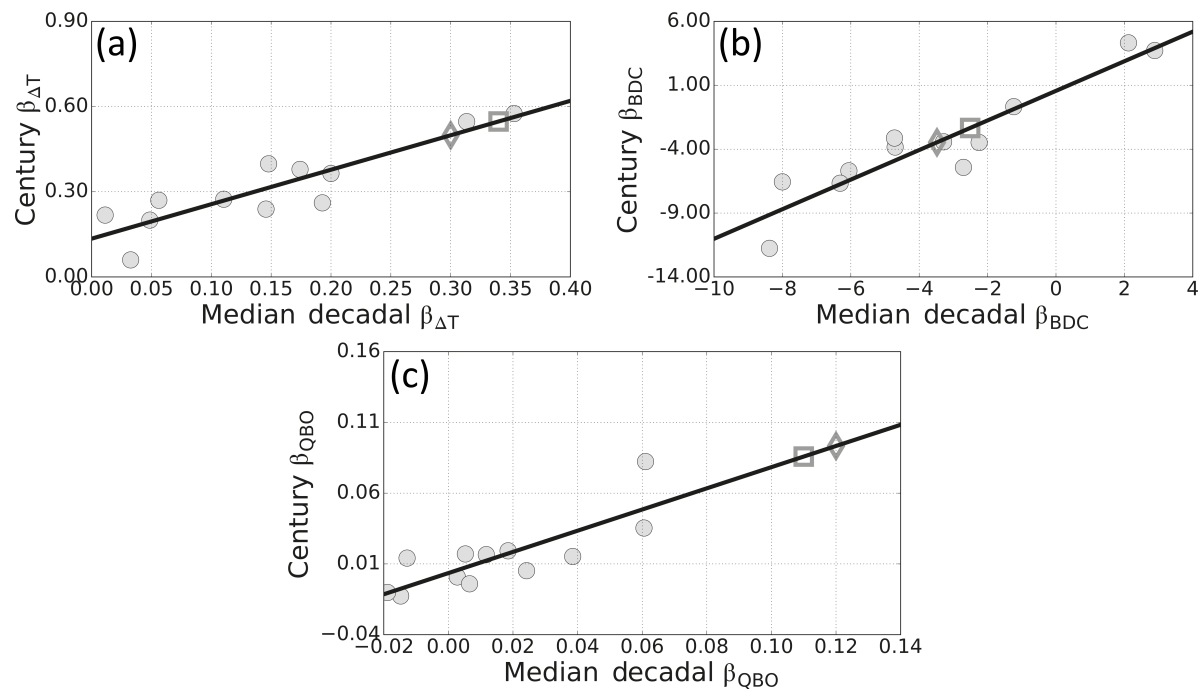

Figure 7. (a) Scatter plots of trended $\Delta T$ regression coefficients (ppmv $\mathrm{K}^{-1}$ ) vs. median decadal $\Delta T$ regression coefficients (ppmv $\mathrm{K}^{-1}$ ) from each CCM. (b) Same as (a), but for BDC coefficients. (c) Same as (a) and (b), but for QBO coefficient. Black lines in all plots correspond to a best-fit line between the trended and decadal coefficients, and the observational coefficients ERAI (square) and MERRA (diamond) are fitted to each line (from Dessler et al., 2014).

For the BDC coefficient, the best-fit line is

$$
\begin{aligned}
& \beta(\mathrm{BDC}, \text { century })=1.16 \pm 0.32 \beta(\mathrm{BDC}, \text { decade }) \\
& \quad+0.56 \pm 1.56
\end{aligned}
$$

The BDC coefficients from the trended MLRs also have a slightly larger magnitude than those from the decadal MLRs. By fitting the observed values of $\beta$ (BDC, decade) through Eq. (3), we predict $\beta$ (BDC, century) values of $\beta$ (BDC, century) of $-3.45 \pm 1.09$ and $-2.34 \pm 1.09$ ppmv $(\mathrm{K} / \text { day })^{-1}$ for MERRA and ERAI regressions, respectively.

For the QBO coefficient, the best-fit line is

$$
\begin{aligned}
& \beta(\mathrm{QBO}, \text { century })=0.75 \pm 0.40 \beta(\mathrm{QBO}, \text { decade }) \\
& \quad+0.004 \pm 0.01
\end{aligned}
$$

The QBO coefficients from the trended MLRs are slightly smaller than those from the decadal MLRs. Again, using 
Eq. (4), we predict $\beta(\mathrm{QBO}$, century) values of $0.09 \pm 0.03$ and $0.09 \pm 0.02$ ppmv for MERRA and ERAI regressions, respectively.

\section{Conclusions}

Climate models predict that tropical lower-stratospheric humidity $\left(\left[\mathrm{H}_{2} \mathrm{O}\right]_{\text {entry }}\right)$ will increase as the climate warms, with important implications for the chemistry and climate of the atmosphere. We demonstrate in this paper that the regression used by Dessler et al. $(2013,2014)$ can be used to quantify the physical processes underlying these model trends and variability in an ensemble of CCMs. Our method is based on regressing $\mathrm{CCM}\left[\mathrm{H}_{2} \mathrm{O}\right]_{\text {entry }}$ time series against three processes that have been shown to be important to $\left[\mathrm{H}_{2} \mathrm{O}\right]_{\text {entry }}$ : tropospheric temperature $(\Delta T)$, the strength of the BrewerDobson circulation (BDC), and the phase of the QBO. Our approach provides insight into model processes not available by simply comparing $\left[\mathrm{H}_{2} \mathrm{O}\right]_{\text {entry }}$ to TTL temperatures.

We do this on two separate timescales: (1) the 21st century and (2) on decadal timescales. Considering all of our analyses, we find that long-term increase in $\left[\mathrm{H}_{2} \mathrm{O}\right]_{\text {entry }}$, in the $\mathrm{CCMs}$, is primarily driven by warming of the troposphere. This is partially offset in most CCMs by an increase in the strength of the Brewer-Dobson circulation, which tends to cool the tropical tropopause layer (TTL) (Randel et al., 2006; Fueglistaler et al., 2014). For shorter-term internal variability, we find variability in the Brewer-Dobson circulation is of greater importance to the variability of $\left[\mathrm{H}_{2} \mathrm{O}\right]_{\text {entry }}$, consistent with Geller and Zhou (2007) and Dessler et al. (2016). The models show little impact from the QBO.

The coefficients from regressions of individual decades in the CCMs can be compared to coefficients from regressions of observations covering a decade. Overall, the CCM ensemble reproduces $\left[\mathrm{H}_{2} \mathrm{O}\right]_{\text {entry }}$ observations well, except for the fact that the CCMs simulate little response to the QBO, in disagreement with the observations (O'Sullivan and Dunkerton, 1997; Randel et al., 1998; Dunkerton, 2001; Fueglistaler and Haynes, 2005; Choiu et al., 2006; Liang et al., 2011; Castanheira et al., 2012; Khosrawi et al., 2013; Kawatani et al., 2014; Tao et al., 2015); this appears to be a deficiency in the models.

That said, the good agreement of the ensemble average hides some spread among the models, particularly in the response to the BDC. Of particular note, the CNRM-CM5-3 and NIWA-UKCA regressions generate positive BDC regression coefficients, contrary to the other models and contrary to our expectations.

Our overall conclusions are encouraging - the models appear to respond to the factors that control $\left[\mathrm{H}_{2} \mathrm{O}\right]_{\text {entry }}$ in realistic ways, providing some confidence in their simulations of $\left[\mathrm{H}_{2} \mathrm{O}\right]_{\text {entry }}$. Nevertheless, our work has pointed out issues that should be resolved. Some models have clear problems, e.g., the models that predict $\left[\mathrm{H}_{2} \mathrm{O}\right]_{\text {entry }}$ will increase with a strengthening BDC. In addition, nearly the entire ensemble does not reproduce the observed variations of $\left[\mathrm{H}_{2} \mathrm{O}\right]_{\text {entry }}$ with the phase of the QBO. This analysis should help the modeling groups refine their models' simulations of the 21 st century.

Data availability. Both the CCMVal-2 (last accessed on 5 May 2017 from URL: http://browse.ceda.ac.uk/browse/badc/ccmval/ data/CCMVal-2) and CCMI-1 (http://catalogue.ceda.ac.uk/uuid/ 9cc6b94df0f4469d8066d69b5df879d5; Hegglin and Lamarque, 2015) data used in this study can be obtained through the British Atmospheric Data Centre (BADC) archive (BADC, 2017).

Author contributions. $\mathrm{KS}$ and $\mathrm{AD}$ performed this analysis and wrote most of this manuscript. The other authors contributed information pertaining to their individual models and helped revise this paper.

Competing interests. The authors declare that they have no conflict of interest.

Acknowledgements. This work was supported by NASA grant NNX14AF15G to Texas A\&M University. We acknowledge the British Atmospheric Data Centre (BADC) for collecting and archiving the CCMVal and CCMI model output. We would like to thank the WACCM group at NCAR and the CNRM-CM5-3 group for model development and making their simulations available to us. Additionally, we would like to thank those involved in GEOSCCM model development, the NASA MAP program, and the high-performance computing resources provided by the NASA Center for Climate Simulation (NCCS). Olaf Morgenstern acknowledges funding by the New Zealand Royal Society Marsden Fund (grant no. 12-NIW-006). Olaf Morgenstern and Guang Zeng wish to acknowledge the contribution of NeSI high-performance computing facilities to the results of this research. Olaf Morgenstern and Guang Zeng were also supported by the NZ Government's Strategic Science Investment Fund (SSIF) through the NIWA programme CACV. New Zealand's national facilities are provided by the NZ eScience Infrastructure and funded jointly by NeSI's collaborator institutions and through the Ministry of Business, Innovation \& Employment's Research Infrastructure programme (https://www.nesi.org.nz). Hideharu Akiyoshi acknowledges the Environment Research and Technology Development Fund, Ministry of Environment, Japan (2-1303), and NEC-SX9/A(ECO) computers at CGER, NIES. The LMDZ-REPRO contribution was supported by the European Project StratoClim (7th Framework Programme, grant agreement 603557) and the SOLSPEC grant from the Centre d'Etude Spatiale (CNES).

Edited by: Paul Young

Reviewed by: two anonymous referees 


\section{References}

Akiyoshi, H., Zhou, L. B., Yamashita, Y., Sakamoto, K., Yoshiki, M., Nagashima, T., Takahashi, M., Kurokawa, J., Takigawa, M., and Imamura, T.: A CCM simulation of the breakup of the Antarctic polar vortex in the years 1980-2004 under the CCMVal scenarios, J. Geophys. Res.-Atmos., 114, d03103, https://doi.org/10.1029/2007JD009261, 2009.

Akiyoshi, H., Nakamura, T., Miyasaka, T., Shiotani, M., and Suzuki, M.: A nudged chemistry-climate model simulation of chemical constituent distribution at northern high-latitude stratosphere observed by SMILES and MLS during the 2009/2010 stratospheric sudden warming, J. Geophys. Res.-Atmos., 121, 1361-1380, https://doi.org/10.1002/2015JD023334, 2016.

Anstey, J. A., Scinocca, J. F., and Keller, M.: Simulating the QBO in an Atmospheric General Circulation Model: Sensitivity to Resolved and Parameterized Forcing, J. Atmos. Sci., 73, 16491665, https://doi.org/10.1175/JAS-D-15-0099.1, 2016.

Austin, J. and Li, F.: On the relationship between the strength of the Brewer-Dobson circulation and the age of stratospheric air, Geophys. Res. Lett., 33, 117807, https://doi.org/10.1029/2006GL026867, 2006.

Bönisch, H., Engel, A., Birner, Th., Hoor, P., Tarasick, D. W., and Ray, E. A.: On the structural changes in the Brewer-Dobson circulation after 2000, Atmos. Chem. Phys., 11, 3937-3948, https://doi.org/10.5194/acp-11-3937-2011, 2011.

Brewer, A. W.: Evidence for a World Circulation Provided by the Measurements of Helium and Water Vapour Distribution in the Stratosphere, Q. J. Roy. Meteorol. Soc., 75, 351-363, https://doi.org/10.1002/qj.49707532603, 1949.

British Atmospheric Data Centre (BADC): CEDA Data Browser, available at: http://browse.ceda.ac.uk/browse/badc/ccmval/data/ CCMVal-2, last access: 5 May 2017.

Castanheira, J. M., Peevey, T. R., Marques, C. A. F., and Olsen, M. A.: Relationships between Brewer-Dobson circulation, double tropopauses, ozone and stratospheric water vapour, Atmos. Chem. Phys., 12, 10195-10208, https://doi.org/10.5194/acp-1210195-2012, 2012.

Choiu, E. W., Thomason, L. W., and Chu, W. P.: Variability of Stratospheric Water Vapor Inferred from SAGE II, HALOE, and Boulder (Colorado) Balloon Measurements, J. Climate, 19, 4121-4133, https://doi.org/10.1175/JCLI3841.1, 2006.

Dee, D. P., Uppala, S. M., Simmons, A. J., Berrisford, P., Poli, P., Kobayashi, S., Andrae, U., Balmaseda, M. A., Balsamo, G., Bauer, P., Bechtold, P., Beljaars, A. C. M., van de Berg, L., Bidlot, J., Bormann, N., Delsol, C., Dragani, R., Fuentes, M., Geer, A. J., Haimberger, L., Healy, S. B., Hersbach, H., Hólm, E. V., Isaksen, L., Kållberg, P., Köhler, M., Matricardi, M., McNally, A. P., Monge-Sanz, B. M., Morcrette, J.-J., Park, B.-K., Peubey, C., de Rosnay, P., Tavolato, C., Thépaut, J.-N., and Vitart, F.: The ERA-Interim reanalysis: configuration and performance of the data assimilation system, Q. J. Roy. Meteorol. Soc., 137, 553597, https://doi.org/10.1002/qj.828, 2011.

Dessler, A. E., Schoeberl, M. R., Wang, T., Davis, S. M., and Rosenlof, K. H.: Stratospheric water vapor feedback, P. Natl. Acad. Sci., 110, 18087-18091, https://doi.org/10.1073/pnas.1310344110, 2013.

Dessler, A. E., Schoeberl, M. R., Wang, T., Davis, S. M., Rosenlof, K. H., and Vernier, J. P.: Variations of stratospheric water va- por over the past three decades, J. Geophys. Res.-Atmos., 119, 12588-12598, https://doi.org/10.1002/2014JD021712, 2014.

Dessler, A. E., Ye, H., Wang, T., Schoeberl, M. R., Oman, L. D., Douglass, A. R., Butler, A. H., Rosenlof, K. H., Davis, S. M., and Portmann, R. W.: Transport of ice into the stratosphere and the humidification of the stratosphere over the 21st century, Geophys. Res. Lett., 43, 2323-2329, https://doi.org/10.1002/2016GL067991, 2016.

Deushi, M. and Shibata, K.: Development of a Meteorological Research Institute chemistry-climate model version 2 for the study of tropospheric and stratospheric chemistry, Papers in Meteorology and Geophysics, 62, 1-46, https://doi.org/10.2467/mripapers.62.1, 2011.

Dhomse, S., Weber, M., and Burrows, J.: The relationship between tropospheric wave forcing and tropical lower stratospheric water vapor, Atmos. Chem. Phys., 8, 471-480, https://doi.org/10.5194/acp-8-471-2008, 2008.

Donnelly, D.: The Fast Fourier Transform For Experimentalist, Part V: Filters., Comput. Sci. Eng., 8, 92-95, https://doi.org/10.1109/MCSE.2006.14, 2006.

Dunkerton, T.: On the Mean meridional mass motions of the stratosphere and mesosphere, J. Atmos. Sci., 58, 7-25, https://doi.org/10.1175/15200469(1978)035<2325:OTMMMM>2.0.CO;2, 2001.

Flury, T., Wu, D. L., and Read, W. G.: Variability in the speed of the Brewer-Dobson circulation as observed by Aura/MLS, Atmos. Chem. Phys., 13, 4563-4575, https://doi.org/10.5194/acp13-4563-2013, 2013.

Forster, P. M. d. F. and Shine, K. P.: Stratospheric water vapour changes as a possible contributor to observed stratospheric cooling, Geophys. Res. Lett., 26, 3309-3312, https://doi.org/10.1029/1999GL010487, 1999.

Fueglistaler, S. and Haynes, P. H.: Control of interannual and longer-term variability of stratospheric water vapor, J. Geophys. Res., 110, https://doi.org/10.1029/2005JD006019, 2005.

Fueglistaler, S., B.Legras, Beljaars, A., Morcrette, J. J., Simmons, A., Tompkins, A. M., and Uppala, S.: The diabatic heat budget of the upper troposphere and lower/mid stratosphere in ECMWF reanalyses, Q. J. Roy. Meteorol. Soc., 135, 21-37, https://doi.org/10.1002/qj.361, 2009a.

Fueglistaler, S., Dessler, A. E., Dunkerton, T. J., Folkins, I., Fu, Q., and Mote, P. W.: Tropical tropopause layer, Rev. Geophys., 47, https://doi.org/10.1029/2008RG000267, 2009b.

Fueglistaler, S., Liu, Y. S., Flannaghan, T. J., Ploeger, F., and Haynes, P. H.: Departure from Clausius-Clapeyron scaling of water entering the stratosphere in response to changes in tropical upwelling, J. Geophys. Res.-Atmos., 119, 1962-1972, https://doi.org/10.1002/2013JD020772, 2014.

Garcia, R. R. and Randel, W. J.: Acceleration of the Brewer-Dobson Circulation due to Increases in Greenhouse Gases, J. Atmos. Sci., 65, 2731-2739, https://doi.org/10.1175/2008JAS2712.1, 2008.

Garcia, R. R., Marsh, D. R., Kinnison, D. E., Boville, B. A., and Sassi, F.: Simulation of secular trends in the middle atmosphere, 1950-2003, J. Geophys. Res.-Atmos., 112, d09301, https://doi.org/10.1029/2006JD007485, 2007.

Geller, M. A. and Zhou, T.: Morphology of Tropical Upwelling in the Lower Stratosphere, J. Atmos. Sci., 65, 2360-2374, https://doi.org/10.1175/2007JAS2421.1, 2007. 
Geller, M. A., Zhou, X., and Zhang, M.: Simulations of the Interannual Variability of Stratospheric Water Vapor, J. Atmos. Sci., 59, 1076-1085, https://doi.org/10.1175/15200469(2002)059<1076:SOTIVO>2.0.CO;2, 2002.

Geller, M. A., Zhou, T., Shindell, D., Ruedy, R., Aleinov, I., Nazarenko, L., Tausnev, N. L., Kelley, M., Sun, S., Cheng, Y., Field, R. D., and Faluvegi, G.: Modeling the QBO - Improvements resulting from higher - model vertical resolution, J. Adv. Model. Earth Syst., 8, 1092-1105, https://doi.org/10.1002/2016MS000699, 2016.

Gettelman, A., Hegglin, M. I., Son, S. W., Kim, J., Fuijiwara, M., Birner, T., Kremser, S., Rex, M., Anel, J. A., Akiyoshi, H., Austin, J., Bekki, S., Braesike, P., Bruhl, C., Butchart, N., Chipperfield, M., Dameris, M., Dhomse, S., Hardimann, H. G. S. C., Jockel, P., Kinnison, D. E., Lamarque, J. F., Mancini, E., Marchand, M., Michou, M., Morgensern, O., Pawson, S., Pitari, G., Plummer, D., Pyle, J. A., Rozanov, E., Scinocca, J., Shepherd, T. G., Shibata, K., Smale, D., Teyssedre, H., and Tian, W.: Multimodel assessment of the upper troposhere and lower stratopshere: Tropics and global trends, J. Geophys. Res., 115, https://doi.org/10.1029/2009JD013638, 2010.

Gilford, D. M., Solomon, S., and Portmann, R. W.: Radiative Impacts of the 2011 Abrupt Drops in Water Vapor and Ozone in the Tropical Tropopause Layer, J. Climate, 29, 595-612, https://doi.org/10.1175/JCLI-D-15-0167.1, 2016.

Hardiman, S. C., Boutle, I. A., Bushell, A. C., Butchart, N., Cullen, M. J. P., Field, P. R., Furtado, K., Manners, J. C., Milton, S. F., Morcrette, C., O’Connor, F. M., Shipway, B. J., Smith, C., Walters, D. N., Willett, M. R., Williams, K. D., Wood, N., Abraham, N. L., Keeble, J., and Maycock, A. C.: Processes Controlling Tropical Tropopause Temperature and Stratospheric Water Vapor in Climate Models., J. Climate, 28, 6516-6535, https://doi.org/10.1175/JCLI-D-15-0075.1, 2015.

Hegglin, M. I. and Lamarque, J.-F.: The IGAC/SPARC Chemistry-Climate Model Initiative Phase-1 (CCMI1) model data output, NCAS British Atmospheric Data Centre, available at: http://catalogue.ceda.ac.uk/uuid/ 9cc6b94df0f4469d8066d69b5df879d5 (last access: 5 May 2017), 2015.

Hegglin, M. I., Plummer, D. A., Shepherd, T. G., Scinocca, J. F., Anderson, J., Froidevaux, L., Funke, B., Hurst, D., Rozanov, A., Urban, J., von Clarmann, T., Walker, K. A., Wang, H. J., Tegtmeier, S., and Weigel7, K.: Vertical structure of stratospheric water vapour trends derived from merged satellite data, Nat. Geosci., 7, 768-776, https://doi.org/10.1038/ngeo2236, 2014.

Holton, J. R., Haynes, P. H., McIntyre, M. E., Douglass, A. R., Rood, R. B., and Phister, L.: Stratospheretroposphere exchange, Rev. Geophys., 33, 403-439, https://doi.org/10.1029/95RG02097, 1995.

Imai, K., Manago, N., Mitsuda, C., Naito, Y., Nishimoto, E., Sakazaki, T., Fujiwara, M., Froidevaux, L., von Clarmann, T., Stiller, G. P., Murtagh, D. P., Rong, P.-p., Mlynczak, M. G., Walker, K. A., Kinnison, D. E., Akiyoshi, H., Nakamura, T., Miyasaka, T., Nishibori, T., Mizobuchi, S., Kikuchi, K.-i., Ozeki, H., Takahashi, C., Hayashi, H., Sano, T., Suzuki, M., Takayanagi, M., and Shiotani, M.: Validation of ozone data from the Superconducting Submillimeter-Wave Limb-Emission Sounder (SMILES), J. Geophys. Res.-Atmos., 118, 5750-5769, https://doi.org/10.1002/jgrd.50434, 2013.
IPCC: Climate Change 2001: The Scientific Basis: Contribution of Working Group 1 to the Third Assessment Report of the Intergovernmental Panel on Climate Change, Tech. rep., Intergovernmental Panel on Climate Change (IPCC), New York, 2001.

Jonsson, A. I., de Grandpré, J., Fomichev, V. I., McConnell, J. C., and Beagley, S. R.: Doubled $\mathrm{CO}_{2}$-induced cooling in the middle atmosphere: Photochemical analysis of the ozone radiative feedback, J. Geophys. Res.-Atmos., 109, d24103, https://doi.org/10.1029/2004JD005093, 2004.

Jourdain, L., Bekki, S., Lott, F., and Lefèvre, F.: The coupled chemistry-climate model LMDz-REPROBUS: description and evaluation of a transient simulation of the period 1980-1999, Ann. Geophys., 26, 1391-1413, https://doi.org/10.5194/angeo26-1391-2008, 2008.

Kawatani, Y., Lee, J. N., and Hamilton, K.: Interannual Variations of Stratospheric Water Vapor in MLS Observations and Climate Model Simulations., J. Atmos. Sci., 71, 4072-4085, https://doi.org/10.1175/JAS-D-14-0164.1, 2014.

Khosrawi, F., Müller, R., Urban, J., Proffitt, M. H., Stiller, G., Kiefer, M., Lossow, S., Kinnison, D., Olschewski, F., Riese, M., and Murtagh, D.: Assessment of the interannual variability and influence of the QBO and upwelling on tracer-tracer distributions of $\mathrm{N}_{2} \mathrm{O}$ and $\mathrm{O}_{3}$ in the tropical lower stratosphere, Atmos. Chem. Phys., 13, 3619-3641, https://doi.org/10.5194/acp13-3619-2013, 2013.

Kim, J., Grise, K. M., and Son, S.-W.: Thermal characteristics of the cold-point tropopause region in CMIP5 models, J. Geophys. Res.-Atmos., 118, 8827-8841, https://doi.org/10.1002/jgrd.50649, 2013.

Li, F., Austin, J., and Wilson, J.: The Strength of the Brewer-Dobson Circulation in a Changing Climate: Coupled Chemistry-Climate Model Simulations, J. Climate, 21, 40-57, https://doi.org/10.1175/2007JCLI1663.1, 2008.

Liang, C. K., Eldering, A., Gettelman, A., Tian, B., Wong, S., Fetzer, E. J., and Liou, K. N.: Record of tropical interannual variability of temperature and water vapor from a combined AIRS-MLS data set, J. Geophys. Res.-Atmos., 116, d06103, https://doi.org/10.1029/2010JD014841, 2011.

Lin, P., Paynter, D., Ming, Y., and Ramaswamy, V.: Changes of the Tropical Tropopause Layer under Global Warming, J. Climate, 30, 1245-1258, https://doi.org/10.1175/JCLI-D-160457.1, 2017.

Manabe, S. and Wetherald, R. T.: Thermal Equilibrium of the Atmosphere with a Given Distribution of Relative Humidity, J. Atmos. Sci., 24, 241-259, https://doi.org/10.1175/15200469(1967)024<0241:TEOTAW>2.0.CO;2, 1967.

Maycock, A. C., Joshi, J. M., Shine, K. P., Davis, S. M., and Rosenlof, K. H.: The potential impact of changes in lower stratospheric water vapour on stratospheric temperatures over the past 30 years, Q. J. Roy. Meteorol. Soc., 26, 2176-2185, https://doi.org/10.1002/qj.2287, 2014.

Meinshausen, M., Smith, S. J., Calvin, K., Daniel, J. S., Kainuma, M. L. T., Lamarque, J.-F., Matsumoto, K., Montzka, S. A., Raper, S. C. B., Riahi, K., Thomson, A., Velders, G. J. M., and van Vuuren, D. P. P.: The RCP greenhouse gas concentrations and their extensions from 1765 to 2300, Climatic Change, 109, 213-241, https://doi.org/10.1007/s10584-011-0156-z, 2011.

Michou, M., Saint-Martin, D., Teyssèdre, H., Alias, A., Karcher, F., Olivié, D., Voldoire, A., Josse, B., Peuch, V.-H., Clark, H., Lee, 
J. N., and Chéroux, F.: A new version of the CNRM ChemistryClimate Model, CNRM-CCM: description and improvements from the CCMVal-2 simulations, Geosci. Model Dev., 4, 873900, https://doi.org/10.5194/gmd-4-873-2011, 2011.

Molod, A., Takacs, L., Suarez, M., Bacmeister, J., Song, I. S., and Eichmann, A.: The GEOS-5 Atmospheric General Circulation Model: Mean Climate and Development from MERRA to Fortuna, NASA Technical Report Series on Global Modeling and Data Assimilation, Tech. Rep. NASA TM-2012-104606, NASA GFSC, 2012.

Molod, A., Takacs, L., Suarez, M., and Bacmeister, J.: Development of the GEOS-5 atmospheric general circulation model: evolution from MERRA to MERRA2, Geosci. Model Dev., 8, 1339-1356, https://doi.org/10.5194/gmd-8-1339-2015, 2015.

Morgenstern, O., Braesicke, P., O’Connor, F. M., Bushell, A. C., Johnson, C. E., Osprey, S. M., and Pyle, J. A.: Evaluation of the new UKCA climate-composition model Part 1: The stratosphere, Geosci. Model Dev., 2, 43-57, https://doi.org/10.5194/gmd-2-43-2009, 2009.

Morgenstern, O., Giorgetta, M. A., Shibata, K., Eyhring, V., Waugh, D. W., Shepherd, T. G., Akiyoshi, H., Austin, J., Baumgaertner, A. J. G., Bekki, S., Braesicke, P., Brühl, C., Chipperfield, M. P., Cugnet, D., Dameris, M., Dhomse, S., Frith, S. M., Garny, H., Gettleman, A., Hardiman, S. C., Hegglin, M. I., Jöckel, P., Kinnison, D. E., Lamarque, J. F., Mancini, E., Manzini, E., Marchand, M., Michou, M., Nakamura, T., Nielsen, J. E., Olivié, D., Pitari, G., Plummer, D. A., Rozanov, E., Scinocca, J. F., Smale, D., Teyssèdre, H., Toohey, M., Tian, W., and Yamashita, Y.: Review of the formulation of present-generation stratospheric chemistryclimate models and associated external forcings, J. Geophys. Res., 115, https://doi.org/10.1029/2009JD013728, 2010.

Morgenstern, O., Zeng, G., Luke Abraham, N., Telford, P. J., Braesicke, P., Pyle, J. A., Hardiman, S. C., O'Connor, F. M., and Johnson, C. E.: Impacts of climate change, ozone recovery, and increasing methane on surface ozone and the tropospheric oxidizing capacity, J. Geophys. Res.-Atmos., 118, 1028-1041, https://doi.org/10.1029/2012JD018382, 2013.

Morgenstern, O., Hegglin, M. I., Rozanov, E., O’Connor, F. M., Abraham, N. L., Akiyoshi, H., Archibald, A. T., Bekki, S., Butchart, N., Chipperfield, M. P., Deushi, M., Dhomse, S. S., Garcia, R. R., Hardiman, S. C., Horowitz, L. W., Jöckel, P., Josse, B., Kinnison, D., Lin, M., Mancini, E., Manyin, M. E., Marchand, M., Marécal, V., Michou, M., Oman, L. D., Pitari, G., Plummer, D. A., Revell, L. E., Saint-Martin, D., Schofield, R., Stenke, A., Stone, K., Sudo, K., Tanaka, T. Y., Tilmes, S., Yamashita, Y., Yoshida, K., and Zeng, G.: Review of the global models used within phase 1 of the Chemistry-Climate Model Initiative (CCMI), Geosci. Model Dev., 10, 639-671, https://doi.org/10.5194/gmd-10-639-2017, 2017.

Mote, P. W., Rosenlof, K. H., McIntyre, M. E., Carr, E. S., Gille, J. C., Holton, J. R., Kinnersley, J. S., Pumphrey III, H. C., J. M. R., and Waters, J. W.: An atmospheric tape recorder: The imprint of tropical tropopause temperatures on stratospheric water vapor, J. Geophys. Res.-Atmos., 101, 3989-4006, https://doi.org/10.1029/95JD03422, 1996.

Okamoto, K., Sato, K., and Akiyoshi, H.: A study on the formation and trend of the Brewer-Dobson circulation, J. Geophys. Res.Atmos., 116, d10117, https://doi.org/10.1029/2010JD014953, 2011.
Oman, L., Waugh, D. W., Pawson, S., Stolarski, R. S., and Nielsen, E. J.: Understanding the Changes of Stratospheric Water Vapor in Coupled Chemistry-Climate Model Simulations, J. Atmos. Sci., 65, 3278-3291, https://doi.org/10.1175/2008JAS2696.1, 2008.

Oman, L. D., Ziemke, J. R., Douglass, A. R., Waugh, D. W., Lang, C., Rodriguez, J. M., and Nielsen, J. E.: The response of tropical tropospheric ozone to ENSO, Geophys. Res. Lett., 38, 113706, https://doi.org/10.1029/2011GL047865, 2011.

Oman, L. D., Douglass, A. R., Ziemke, J. R., Rodriguez, J. M., Waugh, D. W., and Nielsen, J. E.: The ozone response to ENSO in Aura satellite measurements and a chemistryclimate simulation, J. Geophys. Res.-Atmos., 118, 965-976, https://doi.org/10.1029/2012JD018546, 2013.

O'Sullivan, D. and Dunkerton, T. J.: The influence of the quasi-biennial oscillation on global constituent distributions, J. Geophys. Res.-Atmos., 102, 21731-21743, https://doi.org/10.1029/97JD01689, 1997.

Pawson, S., Stolarski, R. S., Douglass, A. R., Newman, P. A., Nielsen, J. E., Frith, S. M., and Gupta, M. L.: Goddard Earth Observing System chemistry-climate model simulations of stratospheric ozone-temperature coupling between 1950 and 2005, J. Geophys. Res.-Atmos., 113, d12103, https://doi.org/10.1029/2007JD009511, 2008.

Randel, W. J. and Thompson, A. M.: Interannual variability and trends in tropical ozone derived from SAGE II satellite data and SHADOZ ozonesondes, J. Geophys. Res.-Atmos., 116, d07303, https://doi.org/10.1029/2010JD015195, 2011.

Randel, W. J., Wu, F., Russell, J. M., Roche, A., and Waters, J. W.: Seasonal cycles and QBO variations in stratospheric $\mathrm{CH}_{4}$ and $\mathrm{H}_{2} \mathrm{O}$ observed in UARS HALOE data, J. Atmos. Sci., 55, 163-185, https://doi.org/10.1175/15200469(1998)055<0163:SCAQVI>2.0.CO;2, 1998.

Randel, W. J., Wu, F., Vömel, H., Nedoluha, G. E., and Forster, P.: Decreases in stratospheric water vapor after 2001: Links to changes in the tropical tropopause and the BrewerDobson circulation, J. Geophys. Res.-Atmos., 111, d12312, https://doi.org/10.1029/2005JD006744, 2006.

Rienecker, M., Suarez, M. J., Gelaro, R., Todling, R., Bacmeister, J., Liu, E., Bosilovich, M. G., Schubert, S. D., Takacs, L., Kim, G. K., Bloom, S., Chen, J., Collins, D., Conaty, A., and Silva, A. D.: MERRA: Nasa's Modern-Era Retrospective Analysis for Research and Applications, J. Climate, 24, 3624-3648, https://doi.org/10.1175/JCLI-D-11-00015.1, 2011.

Rind, D., Jonas, J., Balachandran, N. K., Schmidt, G. A., and Lean, J.: The QBO in two GISS global climate models: 1. Generation of the QBO, J. Geophys. Res.-Atmos., 119, 2014JD021678, 87988824, https://doi.org/10.1002/2014JD021678, 2014.

Rosenlof, K. H., Tuck, A. F., Kelly, K. K., Russell, J. M., and McCormick, M. P.: Hemispheric asymmetries in water vapor and inferences about transport in the lower stratosphere, J. Geophys. Res.-Atmos., 102, 13213-13234, https://doi.org/10.1029/97JD00873, 1997.

Santer, B. D., Wigley, T. M. L., Boyle, J. S., Gaffin, D. J., Hnilo, J. J., Nychka, D., Parker, D. E., and Taylor, K. E.: Statistical significance of trends and trend differences in layer-average atmospheric temperature time series, J. Geophys. Res., 105, 73377356, https://doi.org/10.1029/1999jd901105, 2000.

Scherer, M., Vömel, H., Fueglistaler, S., Oltmans, S. J., and Staehelin, J.: Trends and variability of midlatitude stratospheric 
water vapour deduced from the re-evaluated Boulder balloon series and HALOE, Atmos. Chem. Phys., 8, 1391-1402, https://doi.org/10.5194/acp-8-1391-2008, 2008.

Scinocca, J. F., McFarlane, N. A., Lazare, M., Li, J., and Plummer, D.: Technical Note: The CCCma third generation AGCM and its extension into the middle atmosphere, Atmos. Chem. Phys., 8, 7055-7074, https://doi.org/10.5194/acp-8-7055-2008, 2008.

Shibata, K. and Deushi, M.: Long-term variations and trends in the simulation of the middle atmosphere 1980-2004 by the chemistry-climate model of the Meteorological Research Institute, Ann. Geophys., 26, 1299-1326, https://doi.org/10.5194/angeo-26-1299-2008, 2008.

Seviour, W. J. M., Butchart, N., and Hardiman, S. C.: The BrewerDobson circulation inferred from ERA-Interim, Q. J. Roy. Meteorol. Soc., 138, 878-888, https://doi.org/10.1002/qj.966, 2012.

Sioris, C. E., McLinden, C. A., Fioletov, V. E., Adams, C., Zawodny, J. M., Bourassa, A. E., Roth, C. Z., and Degenstein, D. A.: Trend and variability in ozone in the tropical lower stratosphere over 2.5 solar cycles observed by SAGE II and OSIRIS, Atmos. Chem. Phys., 14, 3479-3496, https://doi.org/10.5194/acp-14-3479-2014, 2014.

Solomon, S., Rosenlof, K. H., Portmann, R. W., Daniel, J. S., Davis, S. M., Sanford, T. J., and Gian-Kasper, P.: Contributions of Stratospheric Water Vapor to Decadal Changes in the Rate of Global Warming, Science, 327, 1219-1223, https://doi.org/10.1126/science.1182488, 2010.

SPARC: SPARC CCMVal Report on the Evaluation of ChemistryClimate Models, Tech. rep., Stratosphere-troposphere Processes and their role in climate (SPARC), available at: http://www. sparc-climate.org/publications/sparc-reports/ (last access: January 2017), 2010.

Stiller, G. P., von Clarmann, T., Haenel, F., Funke, B., Glatthor, N., Grabowski, U., Kellmann, S., Kiefer, M., Linden, A., Lossow, S., and López-Puertas, M.: Observed temporal evolution of global mean age of stratospheric air for the 2002 to 2010 period, Atmos. Chem. Phys., 12, 3311-3331, https://doi.org/10.5194/acp12-3311-2012, 2012.

Tao, M., Konopka, P., Ploeger, F., Grooß, J.-U., Müller, R., Volk, C. M., Walker, K. A., and Riese, M.: Impact of the 2009 major sudden stratospheric warming on the composition of the stratosphere, Atmos. Chem. Phys., 15, 8695-8715, https://doi.org/10.5194/acp-15-8695-2015, 2015.
Voldire, A., Sanchez-Gomez, E., y Melia, D. S., Decharme, B., Cassou, C., Sénési, S., Valcke, S., Beau, I., Alias, A., Chevallier, M., Déqué, M., Deshayes, J., Douville, H., Fernandez, E., Madec, G., Maisonnave, E., Moine, M. P., Planton, S., Saint-Martin, D., Szopa, S., Tyteca, S., Alkama, R., Belamari, S., Braun, A., Coquart, L., and Chauvin, F.: The CNRM-CM5.1 global climate model: description and basic evaluation, Clim. Dynam., 40, 2091-2121, https://doi.org/10.1007/s00382-011-1259-y, 2013.

WMO: Scientific Assessment of Ozone Depletion: 2006, Tech. Rep. 50, Global Ozone Research and Monitoring Project, Geneva, Switzerland, 2007.

WMO: Scientific Assessment of Ozone Depletion: 2014, Tech. Rep. 56, Global Ozone Research and Monitoring Project, Geneva, Switzerland, 2014.

Young, P. J., Rosenlof, K. H., Solomon, S., Sherwood, S. C., Fu, Q., and Lamarque, J.-F.: Changes in Stratospheric Temperatures and Their Implications for Changes in the BrewerDobson Circulation, 1979-2005, J. Climate, 25, 1759-1772, https://doi.org/10.1175/2011JCLI4048.1, 2012.

Yukimoto, S., Yoshimura, H., Hosaka, M., Sakami, T., Tsujino, H., Hirabara, M., Tanaka, T. Y., Deushi, M., Obata, A., Nakano, H., Adachi, Y., Shindo, E., Yabu, S., Ose, T., and Kitoh, A.: Meteorological Research Institute Earth System Model Version 1 (MRIESM1) - Model Description, Tech. Rep. of MRI, Tech. Rep. 64, Meteorological Research Institude, 2011.

Yukimoto, S., Adachi, Y., Hosaka, M., Sakami, T., Yoshimura, H., Hirabara, M., Tanaka, T. Y., Shindo, E., Tsujino, H., Deushi, M., Mizuta, R., Yabu, S., Obata, A., Nakano, H., Koshiro, T., Ose, T., and Kitoh, A.: A new global climate model of the Meteorological Research Institute: MRI-CGCM3 - Model description and basic performance, J. Meteorol. Soc. Jpn., 90, 23-64, https://doi.org/10.2151/jmsj.2012-A02, 2012.

Yulaeva, E., Holton, J. R., and Wallace, J. M.: On the Cause of the Annual Cycle in Tropical Lower-Stratospheric Temperatures, J. Atmos. Sci., 51, 169-174, https://doi.org/10.1175/15200469(1994)051<0169:OTCOTA>2.0.CO;2, 1994.

Zhou, X. L., Geller, M. A., and Zhang, M. H.: Tropical Cold Point Tropopause Characteristics Derived from ECMWF Reanalyses and Soundings, J. Climate, 14, 1823-1838, https://doi.org/10.1175/15200442(2001)014<1823:TCPTCD>2.0.CO;2, 2001. 